\title{
Guidance on the diagnosis and management of asthma among adults in resource limited settings
}

\author{
Bruce J Kirenga ${ }^{1,3}$, Jeremy I Schwartz ${ }^{2}$, Corina de Jong ${ }^{3}$, Thys van der Molen ${ }^{3}$, Martin Okot-Nwang ${ }^{1}$
}

1. Pulmonology unit, Department of Medicine, Makerere University College of Health sciences/Mulago Hospital

2. Department of Internal Medicine, Yale School of Medicine

3. Department of General Practice, Groningen Research Institute for Asthma and COPD (GRIAC), University Medical Center Groningen, University of Groningen, Groningen, The Netherlands

\begin{abstract}
Background: Optimal management of asthma in resource limited settings is hindered by lack of resources, making it difficult for health providers to adhere to international guidelines. The purpose of this review is to identify steps for asthma diagnosis and management in resource limited settings.

Methods: Review of international asthma guidelines and other published studies on diagnosis and management of asthma. Results: We establish that clinical diagnosis of asthma can be made if recurrent respiratory symptoms especially current wheeze or wheeze in the last 12 months are present. Presence of a trigger, other allergic diseases, personal or family history of asthma; clinical improvement and increase in the peak flow and forced expiratory volume in one second of $\geq 12 \%$ after salbutamol administration increases the likelihood of asthma. At diagnosis severity grading, patient education, removal or reduction of trigger should be done. Follow up 2-6 weeks and assessment of control during therapy is essential. Therapy should be adjusted up or down depending on control levels. Patients should be instructed to increase the frequency of their bronchodilators and/or steroids therapy when they start to experience worsening symptoms.

Conclusion: Good quality asthma care can be achieved in resource limited settings by use of clinical data and simple tests. Keywords: Asthma, diagnosis, treatment, management and resource limited settings.

DOI: http://dx.doi.org/10.4314/ahs.v15i4.18

Cite as: Kirenga BJ, Schwartz JI, de Jong C, der Molen Tv, Okot-Nwang M. Guidance on the diagnosis and management of asthma among adults in resource limited settings. Afri Health Sci. 2015;15(4):1189-99. http:/ / dx.doi.org/10.4314/abs.v15i4.18
\end{abstract}

\section{Case scenario}

"A 24-year-old woman presents with shortness of breath, wheezing especially at night for four weeks. She has had to stop her job of hawking fruits on the streets because of these symptoms. Her symptoms are worsened by cold weather, wood smoke and dust. There are cockroaches in her house but she says these do not cause ber any problems.

Prior to the onset of these problems, she had never had any illness similar to this but reports recurrent nasal blockage and sneezing in the morning and evening since childhood. Her mother had

\author{
Corresponding author: \\ Bruce J Kirenga, \\ Pulmonology unit, \\ Department of Medicine, \\ Makerere University College of Health sciences \\ /Mulago Hospital \\ Email: brucekirenga@yahoo.co.uk \\ P.O. Box 7072, Kampala, Uganda
}

asthma all her life and her 1 year old baby has prolonged and recurrent attacks of cough. She has no other medical problems and her last normal menstrual period was two weeks ago.

Peak expiratory flow rate (PEFR) measurements are 200ml/ min and $320 \mathrm{ml} / \mathrm{min}$ before and after administration of salbutamol. Part of her spirometry results are as follows: pre-bronchodilator FEV $=2.8 \mathrm{~L}(63 \%$ predicted) and post-bronchodilator $F E V_{1}=3.18$ ( $84 \%$ predicted).

\section{Introduction}

Asthma is a common chronic disorder of the airways that is characterized by variable and recurring symptoms, airflow obstruction, bronchial hyper-responsiveness, and an underlying inflammatory process. ${ }^{1}$ Global prevalence of asthma is estimated at $10-20 \%$ of adults. ${ }^{2}$ In Uganda, a retrospective chart review found that one in six patients receiving care at the Mulago hospital chest clinic had asthma. ${ }^{3}$ 
Asthma management should follow standardized guidelines in order to optimize outcomes. This is however often not easily achieved in resource limited settings (RLS). Firstly, in many cases no national asthma guidelines are present. Secondly, due to the limited range of diagnostics and pharmaceuticals present in these countries and the high cost of chronic disease management, the already present international guidelines, that require these diagnostics and pharmaceuticals, cannot be easily adapted to local circumstances. As a result, there is great variability in asthma management in RLS. We have performed a critical review of the international asthma guidelines and describe a simple step-by-step process of diagnosing and managing asthma in RLS.

\section{Clinical diagnosis of asthma}

Patients presenting with recurrent symptoms of wheeze, breathlessness, cough (especially at night/morning and/ or with exercise) and chest tightness should be evaluated for asthma. ${ }^{2,4-8}$.

Presence of a specific trigger, other allergic diseases such as allergic rhinitis, a history of improvement of symptoms following past use of bronchodilator drugs (commonly salbutamol), personal or family history of asthma increase the likelihood of asthma., ${ }^{2,4}$

Clinicians should always gather information regarding history of wheeze, even if the patient does not spontaneously mention this. It must be noted that equivalent words for wheeze may not exist in common language. Therefore, healthcare workers (HCWs) should use locally appropriate illustrative phrases and examples to be able to obtain an accurate history of wheeze. Wheezing auscultated on chest examination further increases the possibility of an asthma diagnosis. If a wheeze is not present on normal quiet breathing, ask the patient to forcefully exhale, this may make the wheeze audible.

HCWs should however be aware that in severe forms of asthma, the chest may be silent i.e. no breath sounds at all and no wheeze.

\section{Asthma diagnostic tests}

The commonly available tests for asthma in RLS are the peak expiratory flow rate (PEFR) and spirometry. Both PEFR and spirometry are performed to demonstrate reversible airflow obstruction, the hallmark physiological derangement in asthma.

The PEFR meter measures the maximum flow rate generated during a forceful exhalation starting from full lung inflation (peak flow). On the other hand spirometry also measures peak flow but also measures other lung ventilation parameters such as how much of the air is expelled in the first one second $\left(\mathrm{FEV}_{1}\right)$ and the total amount of air that can be forcefully exhaled from the lungs after a full inspiration (forced vital capacity, FVC). It is more accurate and gives reproducible results than the PEFR meter. ${ }^{2}$

The first step is to demonstrate airflow obstruction. Airflow obstruction on a PEFR meter is present when the patient's PEFR is less than his/her predicted flow according to age, sex, and height or his/her personal best for those with previous measurements (Fig 1). ${ }^{10}$ 
Figure 1: Peak Expiratory Flow Rate - normal values. For use with EU/EN 13826 PEF scale meters only. ${ }^{10}$

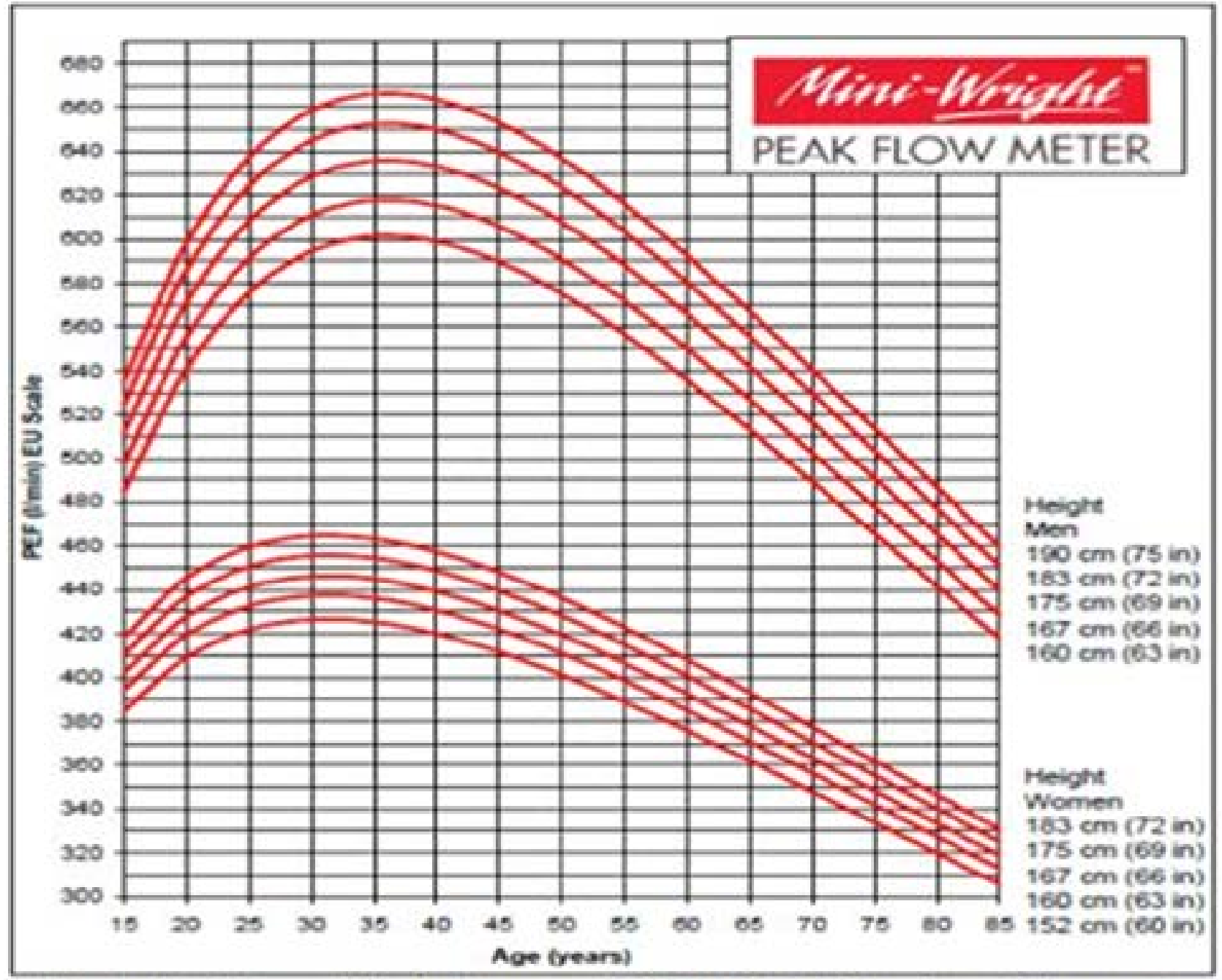

Adapted by Clement Clarke for use with EN13826 / EU scale peak flow meters from Nunn AJ Gregg 1, Br Mod J 1989:298;1068-70

Normal peak expiratory flow rate (PEFR) values can be calculated according to the following formulae: For males PEF,L/minute=[3.95-(0.0151xAge(years)]x height (centimeters) 10 For females $P E F, L /$ minute $=[2.93-(0.0072 x$ Age (years) $] x$ height (centimeters) 10 Alternatively they can be read off directly from nomograms (Fig 1) 44

A short acting bronchodilator is administered and the PEFR is repeated after 15 minutes. An increase of $60 \mathrm{ml}$ or $20 \%$ in the PEFR represents reversible airflow obstruction. ${ }^{2}$ It must be noted however that PEFR is currently not recommended for asthma diagnosis by most international guidelines. ${ }^{2,411}$ However, PEFR provides additional objective evidence of airflow obstruction in the absence of spirometry.

When spirometry testing is done; the patient is tested to determine if the ratio of forced expiratory volume in the first second $\left(\mathrm{FEV}_{1}\right)$ to forced vital capacity (FVC) is less than 0.70 (or less than the lower limit of normal (LLN). After 10-15 minutes two doses of a short acting bronchodilator, separated by one minute, are administered. If there is an improvement in $\mathrm{FEV}_{1}$ of more than $12 \%$ and $200 \mathrm{ml}$, then reversible airflow obstruction is present.
If spirometry is available it should be prioritized for diagnosis and monitoring done using the PEFR measurement in order to reduce costs.

Other asthma tests include the provocation tests to demonstrate airway hyper responsiveness, allergy testing and fraction of exhaled Nitric oxide (FeNO) to demonstrate airway inflammation.

\section{Differential diagnosis}

HCWs should remember that symptoms and signs described above can occur in disease states other than asthma ${ }^{12-14}$. Other diseases with asthma-like symptoms to consider before establishing diagnosis of asthma include: chronic obstructive pulmonary disease (COPD), hyperventilation syndrome, congestive heart failure,pulmonary embolism, mechanical obstruction of the airways (such as occurs in tumours of the lung), vocal cord dysfunction and cough secondary to drugs 
Classification of asthma severity and control level

The possibility of a chronic respiratory infection such as tuberculosis (TB) should always be considered in high TB prevalence settings. We usually obtain sputum microscopy for TB and a chest $\mathrm{x}$-ray as part of initial asthma work up to avoid missing a diagnosis of TB.

A diagnosis of asthma is incomplete without grading of the severity and control of the asthma because treatment choices at the time of diagnosis and during follow up depend on the severity and control levels. ${ }^{2,4}$. Severity grading involves assessing the frequency of the asthma symptoms, physical activity limitation and frequency of using reliever or rescue medications over the past 2-4 weeks. Frequency of exacerbations and results of PEFR and spirometry tests are also used (Table 1). ${ }^{2}$

Table 1: Classifying asthma severity in patients 12 years and older. ${ }^{1}$

\begin{tabular}{|c|c|c|c|c|c|}
\hline \multicolumn{2}{|c|}{ Components of severity } & \multicolumn{4}{|c|}{ Classification of Asthma Severity $>12$ years of age } \\
\hline & & \multirow[b]{2}{*}{ Intermittent } & \multicolumn{3}{|c|}{ Persistent } \\
\hline & & & Mild & Moderate & Severe \\
\hline \multirow[t]{5}{*}{ Impairment } & Symptoms & $\leq 2$ days/week & $\begin{array}{l}>2 / \text { weeks but } \\
\text { not daily }\end{array}$ & Daily & $\begin{array}{l}\text { Throughout } \\
\text { the day }\end{array}$ \\
\hline & $\begin{array}{l}\text { Night time } \\
\text { awakenings }\end{array}$ & $\geq 2 \mathrm{x} /$ month & $3-4 \mathrm{x} /$ month & $\begin{array}{l}>1 \mathrm{x} / \text { week but } \\
\text { not nightly }\end{array}$ & Often $7 x /$ week \\
\hline & $\begin{array}{c}\text { Short-acting } \\
\text { beta }, \text {-agonist } \\
\text { use for } \\
\text { symptom } \\
\text { control (not } \\
\text { prevention of } \\
\text { EIB) } \\
\end{array}$ & $\leq 2$ days/week & $\begin{array}{l}>2 \text { days/week } \\
\text { but not daily, } \\
\text { and not more } \\
\text { than } 1 x \text { on any } \\
\text { day }\end{array}$ & Daily & $\begin{array}{l}\text { Several times } \\
\text { per day }\end{array}$ \\
\hline & $\begin{array}{c}\text { Interference } \\
\text { with normal } \\
\text { activity } \\
\end{array}$ & None & $\begin{array}{l}\text { Minor } \\
\text { limitation }\end{array}$ & $\begin{array}{c}\text { Some } \\
\text { limitation }\end{array}$ & $\begin{array}{l}\text { Extremely } \\
\text { limited }\end{array}$ \\
\hline & Lung function & $\begin{array}{c}\square \text { Normal } \\
\text { FEV } \\
\text { between } \\
\text { exacerbations } \\
\square \mathrm{FEV}_{1}>80 \% \\
\text { predicted } \\
\square{\text { FEV } 1_{1} / \mathrm{FVC}} \\
\text { normal }\end{array}$ & $\begin{array}{c}\text { FEV } \\
>80 \% \\
\text { predicted } \\
\mathrm{FEV}_{1} / \mathrm{FVC} \\
\text { normal }\end{array}$ & $\begin{array}{c}\mathrm{FEV}_{1}> \\
60 \% \text { but }< \\
80 \% \\
\text { predicted } \\
\square \mathrm{FEV} / \mathrm{FVC} \\
\text { reduced by } \\
5 \%\end{array}$ & $\begin{array}{l}\square \quad \mathrm{FEV}_{1} \\
<60 \% \\
\text { predicted } \\
\square \mathrm{FEV}_{1} / \mathrm{FVC} \\
\text { reduced } \\
>5 \%\end{array}$ \\
\hline \multirow[t]{2}{*}{ Risk } & \multirow{2}{*}{$\begin{array}{l}\text { Exacerbations } \\
\text { requiring oral } \\
\text { systemic } \\
\text { corticosteroids }\end{array}$} & $\begin{array}{l}0-1 / \text { year }(\text { see } \\
\text { note })\end{array}$ & \multicolumn{3}{|l|}{$\geq 2 /$ year (see note) } \\
\hline & & \multicolumn{4}{|c|}{$\begin{array}{l}\text { Consider severity and interval since last exacerbation } \\
\text { Frequency and severity may fluctuate over time for patients in any } \\
\text { severity category. } \\
\text { Relative annual risk of exacerbation may be related to FEV }\end{array}$} \\
\hline \multirow{2}{*}{\multicolumn{2}{|c|}{$\begin{array}{l}\text { Recommended Step for } \\
\text { Initiating Treatment (See } \\
\text { "Stepwise approach for } \\
\text { Managing Asthma" for } \\
\text { treatment steps.) }\end{array}$}} & Step 1 & Step 2 & \begin{tabular}{|c|} 
Step 3 \\
and consider sho \\
systemic cortico
\end{tabular} & $\begin{array}{l}\text { Step } 4 \text { or } 5 \\
\text { rt course of oral } \\
\text { steroids }\end{array}$ \\
\hline & & \multicolumn{4}{|c|}{$\begin{array}{l}\text { In } 2-6 \text { weeks, evaluate the level of asthma control that is achieved } \\
\text { and adjust therapy accordingly. }\end{array}$} \\
\hline
\end{tabular}

Asthma severity is classified as intermittent or persistent. Patients with intermittent asthma have a) infrequent asthma symptoms usually less than 2 days per week, b) wake up because of asthma symptoms less than two times a month, and c) experience symptoms requiring rescue medication less than 2 days per week. In addition they have no interference with their physical activity because of asthma; their PEFR and/or spirometry tests results are normal and report either no/ or at most one asthma exacerbation requiring oral systemic glucocorticoids in the previous year. ${ }^{2}$ Persistent asthma is characterized by presence of any one of the features of moderate or severe persistent asthma that is sufficient for classification of moderate and severe persistent asthma, respectively. ${ }^{2}$

Asthma control is defined as the extent to which the various manifestations of asthma are reduced or re- 
moved by treatment. ${ }^{2}$ There are a number of questionnaires that have been designed to assess asthma control but the asthma control test (ACT) is more likely to be easily used in resource limited settings because of its simplicity and no need for tests (Table 2 ). ${ }^{22}$

Table 2. The Asthma Control Test. ${ }^{45}$

Date:

Name of Health Facility

Name of the patient Age Sex

Circle the number of the statement that corresponds to your or your patient's situation Add individual question score and write total in the total score box

1. In the past 4 weeks, how much of the time did your asthma keep you from getting as much done at work, school or at home?

\begin{tabular}{|l|l|c|c|c|}
\hline $\begin{array}{l}\text { All of the } \\
\text { time }\end{array}$ & $\begin{array}{l}\text { Most of the } \\
\text { time }\end{array}$ & Some of the time & $\begin{array}{l}\text { A little of } \\
\text { the time }\end{array}$ & None of the time \\
\hline $\boldsymbol{\nabla}$ & $\boldsymbol{\nabla}$ & $\boldsymbol{\nabla}$ & $\boldsymbol{\nabla}$ & \\
\hline 1 & 2 & 3 & 4 & 5 \\
\hline
\end{tabular}

2. During the past 4 weeks, how often have you had shortness of breath?

\begin{tabular}{|c|c|c|c|c|}
\hline $\begin{array}{l}\text { More than once a } \\
\text { day }\end{array}$ & $\begin{array}{c}\text { Once a } \\
\text { day }\end{array}$ & $\begin{array}{l}3 \text { to } 6 \text { times a } \\
\text { week }\end{array}$ & Once or twice a week & $\begin{array}{l}\text { Not at } \\
\text { all }\end{array}$ \\
\hline 1 & 2 & 3 & 4 & 5 \\
\hline
\end{tabular}

3. During the past 4 weeks, how often did your asthma symptoms (wheezing, coughing, shortness of breath, chest tightness or pain) wake you up at night or earlier than usual in the morning?

\begin{tabular}{|l|c|c|c|c|}
\hline $\begin{array}{l}4 \text { or more nights a } \\
\text { week }\end{array}$ & 2 to 3 nights a & Once a & Once or Twice & Not \\
\hline $\boldsymbol{\nabla}$ & $\boldsymbol{\nabla}$ & $\boldsymbol{\nabla}$ & 4 & 5 \\
\hline 1 & 2 & 3 & & \\
\hline
\end{tabular}

4. During the past 4 weeks, how often have you used your reliever medication (such as your blue inhaler or rescue inhaler)?

\begin{tabular}{|l|c|l|l|l|}
\hline $\begin{array}{l}3 \text { or more times per } \\
\text { day }\end{array}$ & 1 or 2 times per day & $\begin{array}{l}2 \text { or } 3 \text { times } \\
\text { per week }\end{array}$ & Once a week or less & Not at all \\
\hline$\nabla$ & $\nabla$ & $\nabla$ & $\nabla$ & $\nabla$ \\
\hline 1 & 2 & 3 & 4 & 5 \\
\hline
\end{tabular}

5. How would you rate your asthma control during the past 4 weeks?

\begin{tabular}{|l|l|l|l|l|}
\hline Not controlled at all & Poorly controlled & $\begin{array}{l}\text { Somewhat } \\
\text { controlled }\end{array}$ & Well controlled & $\begin{array}{l}\text { Completely } \\
\text { controlled }\end{array}$ \\
\hline$\nabla$ & $\nabla$ & $\nabla$ & $\nabla$ & $\nabla$ \\
\hline 1 & 2 & 3 & 4 & 5 \\
\hline
\end{tabular}

Total Score

Assess asthma control: ${ }^{45}$

Controlled asthma (ACT>19)

Partly controlled asthma (ACT $\geq 15$ and $\leq 19)$

Uncontrolled asthma (ACT<15) 
We recently evaluated the feasibility of using the ACT in our clinic in Uganda in 120 asthma patients attending the Mulago hospital chest clinic and found it to be accurate and feasible. ${ }^{22}$ Controlled patients should be reviewed at 3 months intervals.

The use of the ACT involves asking patients to rate to what extent their asthma symptoms limited their activity, how often they experienced wheezing and how frequent they used reliever medications. They are also asked to rate the frequency of night symptoms and finally to rate their overall control. On basis of the scores obtained, patients are then classified as either controlled asthma (ACT $>19$ ) or inadequately controlled asthma (ACT $\leq 19$ ). ${ }^{22}$ Among those with inadequately controlled asthma 2 categories are considered: partly controlled asthma (ACT $\geq 15$ and $\leq 19)$ and uncontrolled asthma (ACT < 15). The lowest ACT score is 5 and the highest 25 .

\section{Asthma management}

\section{Patient education and trigger avoidance}

Because asthma is a chronic disease, patients should be educated to understand the nature of their illness with a focus on common asthma triggers, warning signs of exacerbations (attacks) and the commonly used asthma drugs and inhaler techniques. Patients should contemplate what their asthma trigger might be and once identified they should be assisted to work towards the reduction or removal of the trigger. ${ }^{2}$ Common triggers include: cockroaches, fur/haired animals like cats and dogs, pollen, molds ${ }^{15}$, domestic mites, indoor and outdoor pollutants ${ }^{15,16}$, viral infections, drugs such as noncardio-selective beta blockers, ACE inhibitors, aspirin and other non-steroidal anti-inflammatory drugs. ${ }^{17,18,19}$

Patients with asthma should be educated about other diseases that worsen asthma especially allergic rhinitis. $^{20,21}$ In one study at Mulago hospital assessing the level of asthma control, presence of rhinitis symptoms was associated with a 5 fold increase in poor asthma control. ${ }^{22}$

\section{Asthma drug therapy}

Asthma drugs are classified as either relievers or controllers or more broadly as either bronchodilator or anti-inflammatory drugs (Table 3).,2,423

Table 3: Commonly available asthma drugs. ${ }^{1}$

\begin{tabular}{|c|c|c|c|c|}
\hline Category & Class & Drug names & $\begin{array}{l}\text { Route of } \\
\text { administration }\end{array}$ & Class main side effects \\
\hline \multirow[t]{5}{*}{ Relievers } & \multirow[t]{3}{*}{$\begin{array}{l}\text { Short acting beta } 2 \\
\text { agonists }(\mathrm{SABA})\end{array}$} & salbutamol & $\begin{array}{l}\text { Oral, inhalation } \\
(+ \text { nebulization) }\end{array}$ & \multirow{3}{*}{$\begin{array}{l}\text { Tachycardia, skeletal } \\
\text { muscle tremor, increased lactic acid } \\
\text { Hypokalemia, headache, and } \\
\text { hyperglycemia. }\end{array}$} \\
\hline & & Levalbuterol & inhalation & \\
\hline & & Adrenaline & $\begin{array}{l}\text { Subcutaneous } \\
\text { injection }\end{array}$ & \\
\hline & $\begin{array}{l}\text { Short acting } \\
\text { antimuscarinics }\end{array}$ & Ipratropium & $\begin{array}{l}\text { inhalation } \\
(+ \text { nebulization })\end{array}$ & $\begin{array}{l}\text { Drying of mouth, increased } \\
\text { wheezing in some individuals, } \\
\text { blurred vision if sprayed in eyes }\end{array}$ \\
\hline & Theophylline & Aminophylline & parenteral/oral & $\begin{array}{l}\text { Tachycardia, nausea and vomiting, } \\
\text { tachyarrhythmia (SVT), headache, } \\
\text { seizures, hematemesis, } \\
\text { hyperglycemia, and hypokalemia, } \\
\text { insomnia, gastric upset, increase in } \\
\text { hyperactivity in some children, } \\
\text { difficulty in urination in elderly } \\
\text { males who have prostatism. }\end{array}$ \\
\hline \multirow{17}{*}{ Controllers } & \multirow[t]{3}{*}{$\begin{array}{l}\text { Long acting beta } \\
\text { agonists (LABA) }\end{array}$} & Salmeterol & $\begin{array}{l}\text { inhalation(+ } \\
\text { nebulization) }\end{array}$ & \multirow{8}{*}{$\begin{array}{l}\text { Short-term use: reversible } \\
\text { abnormalities in glucose } \\
\text { metabolism, increased appetite, } \\
\text { fluid retention, weight gain, facial } \\
\text { flushing, mood alteration, } \\
\text { hypertension, peptic ulcer, and } \\
\text { rarely aseptic necrosis. May worsen } \\
\text { infections, hypertension, peptic } \\
\text { ulcer, diabetes mellitus, } \\
\text { osteoporosis, and Strongyloides }\end{array}$} \\
\hline & & formoterol & inhalation & \\
\hline & & Aformometerol & $\begin{array}{l}\text { inhalation } \\
(+ \text { nebulization })\end{array}$ & \\
\hline & Corticosteroids & & & \\
\hline & \multirow[t]{4}{*}{ Systemic } & Prednisolone & Oral & \\
\hline & & hydrocortisone & oral/parenteral & \\
\hline & & dexamethasone & oral/parenteral & \\
\hline & & methyl prednisolone & Parenteral & \\
\hline & \multirow[t]{5}{*}{ Inhaled } & beclomethasone & oral & \multirow{5}{*}{$\begin{array}{l}\text { Cough, dysphonia, oral thrush } \\
\text { (Candidiasis). Systemic effects may } \\
\text { occur. In low-to medium } \\
\text { doses, suppression of growth } \\
\text { velocity has been observed in } \\
\text { children, but this effect may } \\
\text { be transient }\end{array}$} \\
\hline & & budesonide & Oral/inhalation & \\
\hline & & fluticasone, & Inhalation & \\
\hline & & mometasone & Inhalation & \\
\hline & & Ciclesonide & Inhalation & \\
\hline & \multirow[t]{2}{*}{ In combination with } & $\begin{array}{l}\text { Budesonide with } \\
\text { formoterol }\end{array}$ & Inhalation & \multirow[t]{2}{*}{ See individual drugs } \\
\hline & & $\begin{array}{l}\text { Fluticasone with } \\
\text { salmeterol }\end{array}$ & Inhalation & \\
\hline & \multirow[t]{2}{*}{ Leukotriene modifiers } & Montelukast & Oral & $\begin{array}{l}\text { No specific adverse effects have } \\
\text { been identified, Churg- Strauss and } \\
\text { hepatitis }\end{array}$ \\
\hline & & Zafirlukast & Oral & \\
\hline
\end{tabular}


Reliever asthma drugs are bronchodilators that act fast usually within the first few minutes. For short acting beta agonists (SABA) (Salbutamol and Levalbuterol) the onset of action can be expected within 5 minutes, peaking at 30-60 minutes and lasts 4-6 hours. ${ }^{24,25}$ Because of this rapid onset of action, these drugs are used in the treatment of acute relief of acute asthma symptoms. Ipratropium is another reliever medication with a different mechanism of action. Ipratropium is a short acting anticholinergic agent (onset of action can be expected within 30-40 minutes) which can be used in combination with salbutamol. ${ }^{23,26-28}$ Adrenaline (epinephrine), an injectable short acting non selective $\beta$-agonist has been used in the past for management of acute asthma and is still listed on the WHO essential medicines list. ${ }^{29} \mathrm{It}$ is no longer recommended for use unless no alternative is available in an emergency situation. Short acting theophylline such as aminophylline may be used for quick relief of symptoms if SABAs are not available. ${ }^{29}$ Long acting beta agonists (LABA) are bronchodilators that usually have a slow onset of action but with a long duration of action. Examples LABAs include Salmetrol and Formeterol. LABAs usually come in combination with ICS as combination inhalers. These combination inhalers are not on the WHO essential medicine list but are increasingly becoming available in RLS as generics. ${ }^{5}$

Controller medications are the main stay of asthma management because they target the underlying inflammatory process. ${ }^{30,31}$ Controller drugs include corticosteroids, Leukotriene modifiers and anti- Immunoglobulin E therapy. ${ }^{2,4}$

Corticosteroids (CS) are available in systemic (tablet, solution for injection) and inhalation forms. Although
WHO recommends only beclomethasone and budesonide, fluticasone is also currently available. Inhaled corticosteroids (ICS) are available in low dose, medium dose and high dose inhalers. ${ }^{2}$ Classification of the inhaler as low, medium or high dose depends on the amount of ICS per dose/puff of the inhaler. For beclomethasone and fluticasone, low dose is usually up to $250 \mathrm{mcg} /$ dose/puff, medium dose is up $500 \mathrm{mcg}$ and high dose is $500 \mathrm{mcg}$ or more. When considering Budesonide low dose is up to $400 \mathrm{mcg}$, medium dose is up $800 \mathrm{mcg}$ while high dose is $800 \mathrm{mcg}$ and above. ${ }^{32} \mathrm{HCW}$ s should familiarize with these doses because different asthma severity grades require different ICS dose even of the same inhaler.

Systemic steroids commonly used in the management of asthma include prednisolone, hydrocortisone, and methyl prednisolone.

Other controller drugs include leukotriene modifiers such as montelukast and zafirlukast 2,23,33,34 and theophylline drugs such as aminophylline. ${ }^{35}$ Because theophylline drugs increase CS sensitivity their use in combination with CS may have additive clinical benefits. ${ }^{35}$

There is no role for routine antibiotics in the management of asthma. In many RLS HCWs usually prescribe antibiotics for asthma patients. ${ }^{3,36,37}$ In one study in Uganda almost half of asthma patients were prescribed antibiotics. $^{3}$

\section{How to initiate asthma drugs}

Before initiating asthma drugs a firm diagnosis of asthma must be made. Asthma severity or level of control must also be assessed. Drugs are then initiated and stepped up or down until asthma is brought under control (Table 4):

\section{Table 4. Assessing asthma control and adjusting therapy in youths $>12$ years of age and adults. ${ }^{1,8}$}

\begin{tabular}{|c|c|c|c|c|c|}
\hline \multicolumn{2}{|c|}{ Components of Control } & \multicolumn{4}{|c|}{ Classification of Asthma Control $(\geq 12$ years of age $)$} \\
\hline & & Well Controlled & $\begin{array}{l}\text { Not } \\
\text { Well Controlled }\end{array}$ & $\begin{array}{l}\text { Very } \\
\text { Controlled }\end{array}$ & Poorly \\
\hline \multirow[t]{5}{*}{ Impairment } & Symptoms & $\leq 2$ days/week & $>2$ days/week & Throughout the day & \\
\hline & Nighttime awakenings & $\leq 2 \mathrm{x} /$ month & $1-3 \mathrm{x} /$ week & $\geq 4 \mathrm{x} /$ week & \\
\hline & $\begin{array}{l}\text { Interference with normal } \\
\text { activity }\end{array}$ & None & Some limitation & Extremely limited & \\
\hline & $\begin{array}{l}\text { Short-acting beta2- } \\
\text { agonist use for } \\
\text { symptom } \\
\text { control (not prevention of } \\
\text { EIB) }\end{array}$ & $\leq 2$ days/week & $>2$ days/week & Several times per day & \\
\hline & FEV1 or peak flow & $\begin{array}{l}>80 \% \text { predicted/ } \\
\text { personal best }\end{array}$ & & & \\
\hline
\end{tabular}

Key: $F E V 1=$ forced expiratory volume in one second 
Step 1(Intermittent asthma): Initiate treatment at step1: SABA inhaler to use as needed. HCWs should however note that patients who have seasonal asthma, asthma in which the trigger may not be removed easily or in the short term, those who have had more than two exacerbations in the previous year should be managed as persistent asthma until the trigger or season is over.

Step 2 (Mild persistent asthma): Initiate daily low dose ICS such as beclomethasone and as-needed SABA. Alternative to ICS include leukotriene receptor antagonists or sustained release theophylline.

Step 3 (Moderate persistent asthma): In addition to as-needed SABA plus daily low dose ICS used in Step 2, addition of LABA is recommended preferably as an ICS/LABA combination inhaler. HCWs should note that LABAs should never be used as when not in combination with ICS for asthma treatment because of progressive airway remodeling, increased risk of exacerbations and death. ${ }^{7,38}$

Step 4(Severe persistent asthma): As in step 3 but use medium dose ICS.
Step 5: High dose ICS plus a LABA: International guidelines recommend use of a biologic agent; omalizumab in patients in who an allergen has been identified. This drug is far too costly to be used in RLS. We tend to add oral steroids for patients in this group.

Step 6: Patients in this group will require daily oral steroids until control is achieved.

Once treatment is initiated the patient should be followed over 2-6 weeks to assess control using the ACT. ${ }^{2}$ Controlled patients should be reviewed at scheduled intervals ranging from 3 months to a year. Controlled patients can have their treatments stepped down to suite their asthma severity. Before stepping up or down therapy it is advisable to always check whether the diagnosis of asthma is correct, inhaler technique is correct, presence of perpetuating factors (triggers) that may not have been addressed and presence of a comorbid condition that may be aggravating asthma symptoms. ${ }^{2}$

\section{Asthma exacerbations}

Some asthma patients will present for the first time with exacerbations (also called asthma attacks) or develop one while under follow-up (Table 5).

Table 5. Classification of asthma exacerbations. ${ }^{1}$

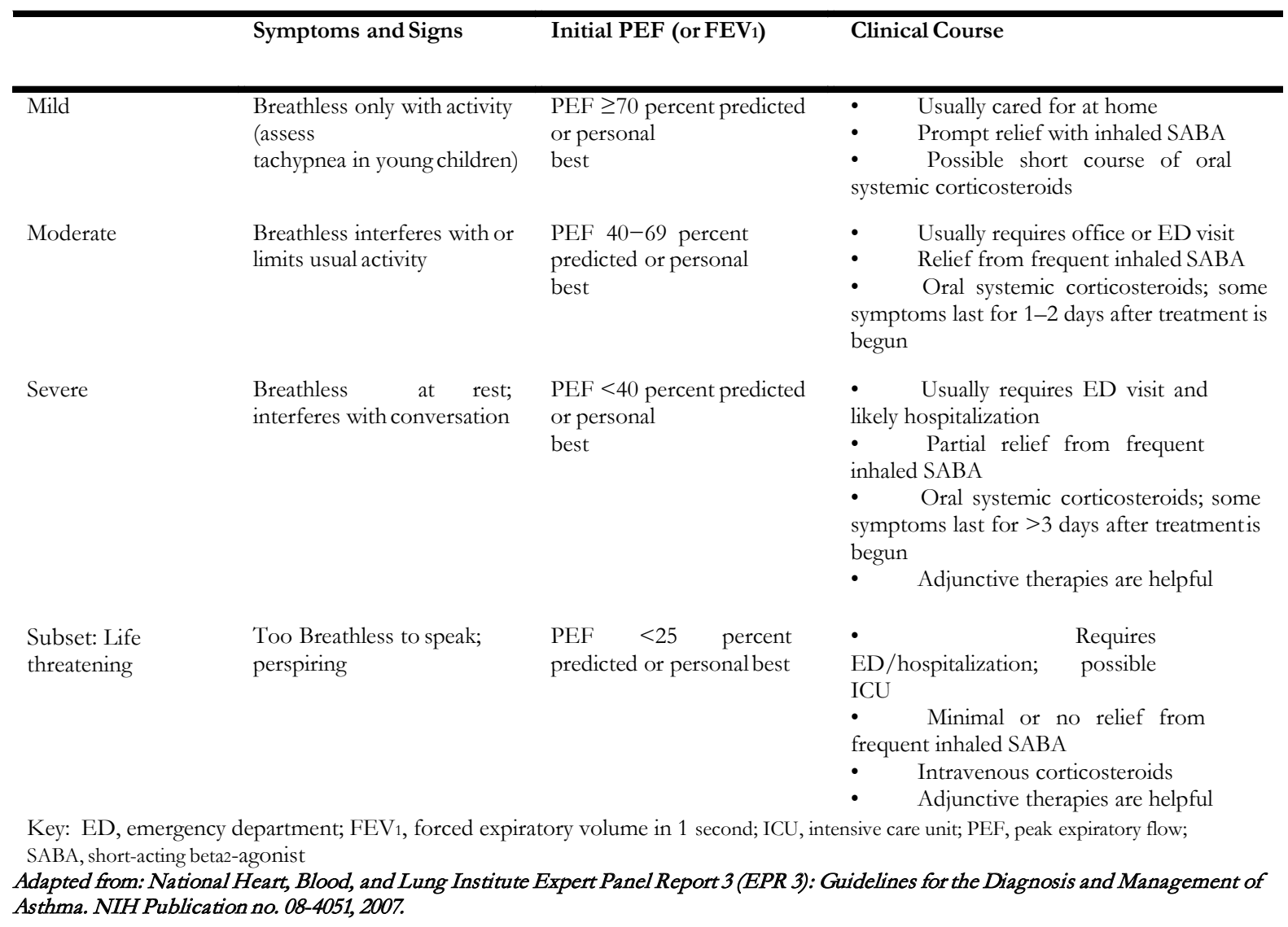


Indication of presence of an asthma exacerbation can be obtained from the history of progressive increase in shortness of breath, chest tightness, cough, wheezing or a combination of these symptoms. ${ }^{2}$ Objective evidence of worsening asthma can be obtained by documenting decreases in expiratory flow (PEFR or $\mathrm{FEV}_{1}$ ) by the HCW. Patients should be educated about recognizing worsening symptoms and to increase the frequency of their reliever inhalers immediately and to seek medical attention. There is emerging evidence that quadrupling of the ICS as soon as patients realize increase in their symptoms may help avert an impending exacerbation. ${ }^{39}$

All patients with asthma exacerbations should receive a course of systemic (preferably oral) of CS. Commonly we use $30-40 \mathrm{mg}$ of prednisolone. ${ }^{1}$

Mild to moderate exacerbation can be managed by repeated administration of SABA 2-4 puffs every $20 \mathrm{~min}-$ utes for 1 hour followed by 2-4 puffs every 3-4 hours. ${ }^{2}$ Use of a spacer or valve holding chamber improves drug delivery and should be used whenever available. ${ }^{40}$, ${ }^{41}$ Moderate exacerbations require 6-10 puffs every 1-2 hours after the initial 1 hour. $^{2}$

Once there is sufficient improvement in clinical parameters and the PEFR or FEV ${ }_{1}$ has been increased back to $>80 \%$ predicted, patients can be monitored for 3-4 hours and if the response is maintained they can then be discharged. A short course of oral steroids can be initiated while the patient is still in the health facility for about 5-7 days in patients with moderate exacerbation. ${ }^{2}$

When available, severe exacerbations should be managed with nebulized SABA $2.5-5 \mathrm{mg}$ diluted to $3 \mathrm{ml}$ with normal saline every 20 minutes for 1 hour and then as needed until there is improvement. Whenever possible, oxygenation should be monitored by pulse oximetry in patients with moderate to severe exacerbations. Supplemental oxygen should be administered to achieve an $\mathrm{SPO}_{2}$ of $>90 \%$. $^{2}$ Systemic oral steroids should also be administered during hospitalization and continued after discharge for 5-7days. Ipratropium may be added to the nebulization chamber along with salbutamol because this has been found to lead to better improvement than salbutamol nebulization alone. ${ }^{2,32,42}$

An alternative for facilities where nebulization cannot be done is use of intravenous theophylline and frequent SABA inhaler use. It must be noted that use aminophylline is not currently recommended because of lack additional benefit after administration of inhaled beta agonist and due to increased side effects. ${ }^{43}$ Epinephrine (adrenaline) is still listed as an essential asthma medicine on the WHO essential medicines list. ${ }^{29}$ Adrenaline has a major role in patients with airway obstruction due to angioedema and other anaphylaxis situation but offers no additional benefit when SABAs have been administered as described. Its use should be discouraged. ${ }^{2}$

\section{Back to the case scenario}

The patient presented had classical recurrent asthma symptoms. She has historyof other allergic diseases (allergic rbinitis). Although she has no personal history of asthma, she has a strong family history of asthma. Triggers (dust, cold weather and smoke) were identified.

The patient's PEFR and FEV1 are both below her predicted normal values and increase by greater than 12\% following bronchodilator administration. Therefore this patient most likely has asthma. Reported daily symptoms, limited physical activity, and moderate airflow obstruction as evidenced by her PEFR and FEV ${ }_{1}$ places this patient in the moderate persistent asthma. ACT should be administered and counselling should be done to reduce exposure to the triggers. Low dose ICS should be initiated as well as a LABA inhaler. As needed inbaled $S A B A$ should also be maintained for use when the patient experiences asthma symptoms.

Exercise related breathlessness can be prevented by taking 2 doses of inbaled salbutamol / LABA 10-15 minutes before going for her work or leukotriene modifiers such as montelukast. Starting to walk slowly and pace up can also prevent the exercise inducedbreathlessness.

\section{Conclusion}

Although resources to adhere to international asthma guidelines are not available in most RLS good quality evidence based asthma care can be achieved if HWs consistently use clinical data, available tests, drugs and nondrug care in a step by step fashion.

\section{References}

1. National Institutes of Health (2007). National Asthma Education and Prevention Program Expert Panel Report 3: Guidelines for the Diagnosis and Management of Asthma (NIH Publication No. 08-5846).

2. Global Alliance against Chronic Respiratory Diseases Action Plan 2008-2013. Geneva: WHO, 2008.

3. Kirenga J, Okot-Nwang M. The proportion of asthma and patterns of asthma medications prescriptions among adult patients in the chest, accident and emergency units of a tertiary health care facility in Uganda. African Health Sciences 2012; 12(1): 48-53.

4. Levy ML, Fletcher M, Price DB, Hausen T, Halbert RJ, Yawn BP. International Primary Care Respiratory 
Group (IPCRG) Guidelines: diagnosis of respiratory diseases in primary care. Prim Care Respir J 2006; 15(1): 20-34.

5. Van Weel C, Bateman ED, Bousquet J, et al. Asthma management pocket reference 2008. Allergy 2008; 63(8): 997-1004.

6. Williams SG, Schmidt DK, Redd SC, Storms W. Key clinical activities for quality asthma care. Recommendations of the National Asthma Education and Prevention Program. MMWR Recomm Rep 2003; 52(RR-6): 1-8. 7. Expert Panel Report 3 (EPR-3): Guidelines for the Diagnosis and Management of Asthma-Summary Report 2007. J Allergy Clin Immunol 2007; 120(5 Suppl): S94-138.

8. Global Strategy for Asthma Management and Prevention http://www.ginasthma.com.Accessed December 2, 2008).

9. Van der Molen T, Ostrem A, Stallberg B, Ostergaard MS, Singh RB. International Primary Care Respiratory Group (IPCRG) Guidelines: management of asthma. Prim Care Respir J 2006;15(1): 35-47.

10. Leiner GC, Abramowitz S, Small MJ, Stenby VB, Lewis WA. Expiratory Peak Flow Rate. Standard Values for Normal Subjects. Use as a Clinical Test of Ventilatory Function. Am Rev Respir Dis 1963; 88: 644-51.

11. Hankinson JL, Wagner GR. Medical screening using periodic spirometry for detection of chronic lung disease. Occup Med 1993; 8(2): 353-61.

12. Pratter MR, Hingston DM, Irwin RS. Diagnosis of bronchial asthma by clinical evaluation. An unreliable method. Chest 1983; 84(1): 42-7.

13. Acimovic S, Plavec G, Tomic I, Karlicic V, Vukovic J, Loncarevic O. [Symptoms, physical findings and bronchial hypersensitivity in patients with bronchial asthma and normal spirometry]. Vojnosanit Pregl 2009; 66(1): 39-43.

14. Busse WW. What is the best pulmonary diagnostic approach for wheezing patients with normal spirometry? Respir Care 2012; 57(1): 39-46.

15. Wjst M, Boakye D. Asthma in Africa. PLoS Med 2007; 4(2).

16. Pilotto LS, Nitschke M, Smith BJ, et al. Randomized controlled trial of unflued gas heater replacement on respiratory health of asthmatic schoolchildren. Int J Epidemiol 2004; 33(1): 208-14.

17. Benson MK, Berrill WT, Cruickshank JM, Sterling GS. A comparison of four beta- adrenoceptor antagonists in patients with asthma. Br J Clin Pharmacol 1978; 5(5): 415-9.

18. Lunde H, Hedner T, Samuelsson O, et al. Dyspnoea, asthma, and bronchospasm in relation to treat- ment with angiotensin converting enzyme inhibitors. BMJ 1994; 308(6920): 18-21.

19. Vally H, Taylor ML, Thompson PJ. The prevalence of aspirin intolerant asthma (AIA) in Australian asthmatic patients. Thorax 2002; 57(7): 569-74.

20. Harding SM. Recent clinical investigations examining the association of asthma and gastroesophageal reflux. Am J Med 2003; 18(115): 39S-44S.

21. Harding SM. Gastroesophageal reflux and asthma: insight into the association. J Allergy Clin Immunol 1999; 104(2 PubMed Pt 1): 251-9.

22. Serugendo AN, Kirenga BJ, Hawkes M, Nakiyingi L, Worodria W, Okot-Nwang M. Evaluation of asthma control using Global Initiative for Asthma criteria and the Asthma Control Test in Uganda. Int J Tuberc Lung Dis 2014; 18(3): 371-6.

23. Fanta CH. Asthma. N Engl J Med 2009; 360(10): 1002-14.

24. Johnson M. Beta2-adrenoceptors: mechanisms of action of beta2-agonists. Paediatr Respir Rev 2001; 2(1): 57-62.

25. Johnson M. Molecular mechanisms of beta(2)-adrenergic receptor function, response, and regulation. $J$ Allergy Clin Immunol 2006; 117(1): 18-24.

26. Fryer AD, Jacoby DB. Muscarinic receptors and control of airway smooth muscle. Am J Respir Crit Care Med 1998; 158(5 PubMed Pt 3): S154-60.

27. Barnes PJ. Muscarinic receptors in airways: recent developments. J Appl Physiol 1985; 68(5): 1777-85.

28. Gross NJ. Tiotropium bromide. Chest 2004; 126(6): 1946-53.

29. WHO Model List of Essential Medicines, 18th list (April 2013), (Final Amendments - October 2013). http:/ /www.who.int/medicines/publications/essentialmedicines/18th_EML.pdf (accessed June 10 2014).

30. Van der Velden VH. Glucocorticoids: mechanisms of action and anti-inflammatory potential in asthma. Mediators Inflamm 1998; 7(4): 229-37.

31. Barnes PJ. Anti-inflammatory actions of glucocorticoids: molecular mechanisms: Clin Sci (Lond). 1998 Jun;94(6):557-72.

32. Stoodley RG, Aaron SD, Dales RE. The role of ipratropium bromide in the emergency management of acute asthma exacerbation: a metaanalysis of randomized clinical trials. Ann Emerg Med 1999; 34(1): 8-18. 33. O'Byrne PM, Israel E, Drazen JM. Antileukotrienes in the treatment of asthma. Ann Intern Med 1997; 127(6): 472-80.

34. Drazen JM, Israel E, O'Byrne PM. Treatment of asthma with drugs modifying the leukotriene pathway. N Engl J Med 1999; 340(3): 197-206. 
35. Hansel T'T, TennantRC, Tan AJ, et al. Theophylline: mechanism of action and use in asthma and chronic obstructive pulmonary disease. Drugs Today 2004; 40(1): 55-69.

36. Spahn JD, Fost DA, Covar R, et al. Clarithromycin potentiates glucocorticoid responsiveness in patients with asthma: results of a pilot study. Ann Allergy Asthma Immunol 2001; 87(6): 501-5.

37. Thomson NC, Chaudhuri R, Spears M. Emerging therapies for severe asthma. BMC Med 2011; 9(102): 1741-7015.

38. Salpeter SR, Buckley NS, Ormiston TM, Salpeter EE. Meta-analysis: effect of long-acting beta-agonists on severe asthma exacerbations and asthma-related deaths. Ann Intern Med 2006;144(12): 904-12.

39. Oborne J, Mortimer K, Hubbard RB, Tattersfield AE, Harrison TW. Quadrupling the dose of inhaled corticosteroid to prevent asthma exacerbations: a randomized, double-blind, placebo-controlled, parallel-group clinical trial. Am J Respir Crit Care Med 2009; 180(7): 598-602.

40. Turner JR, Corkery KJ, Eckman D, Gelb AM, Lipavsky A, Sheppard D. Equivalence of continuous flow nebulizer and metered-dose inhaler with reservoir bag for treatment of acute airflow obstruction. Chest 1988; 93(3): 476-81.

41. Idris AH, McDermott MF, Raucci JC, Morrabel A, McGorray S, Hendeles L. Emergency department treatment of severe asthma. Metered-dose inhaler plus holding chamber is equivalent in effectiveness to nebulizer. Chest 1993; 103(3): 665-72.

42. Fiel SB, Swartz MA, Glanz K, Francis ME. Efficacy of short-term corticosteroid therapy in outpatient treatment of acute bronchial asthma. Am J Med 1983; 75(2): 259-62.

43. Parameswaran K, Belda J, Rowe BH. Addition of intravenous aminophylline to beta2- agonists in adults with acute asthma. Cochrane Database Syst Rev 2000; 4. 44. Peak Expiratory Flow Rate - normal values. For use with EU/EN 13826 PEF scale meters only. http:// www.peakflow.com/pefr_normal_values.pdf (accessed February 2014.

45. Nathan RA, SorknessCA, Kosinski M, et al. Development of the asthma control test: a survey for assessing asthma control. J Allergy Clin Immunol 2004; 113(1): 59-65. 